\title{
Phylogenetic relationships of Scomberomorus commerson using sequence analysis of the mtDNA D-loop region in the Persian Gulf, Oman Sea and Arabian Sea
}

\author{
Ana Mansourkiaei - Pargol Ghavam Mostafavi - Seyed Mohammad Reza Fatemi • \\ Farhad Kaymaram • Ali Nazemi
}

Received: 27 July 2015/Accepted: 21 March 2016/Published online: 19 April 2016

(C) The Author(s) 2016. This article is published with open access at Springerlink.com

\begin{abstract}
Narrow-barred Spanish mackerel, Scomberomorus commerson, is an epipelagic and migratory species of family Scombridae which have a significant role in terms of ecology and fishery. 100 samples were collected from the Persian Gulf, Oman Sea and Arabian Sea. Part of their dorsal fins was snipped and transferred to micro-tubes containing ethanol; then, DNAs were extracted and HRM-Real Time PCR was performed to designate representative specimens for sequencing. Phylogenetic relationships of S. commerson from Persian Gulf, Oman Sea and Arabian Sea were investigated using sequence data of mitochondrial DNA D-loop region. None clustered Neighbor Joining tree indicated the proximity amid $S$. commerson in four sites. As numbers demonstrated in sequence analyses of mitochondrial DNA D-Loop region a sublimely high degree of genetic similarity among S. commerson from the Persian Gulf and Oman Sea were perceived, thereafter, having one stock structure of $S$. commerson in four regions were proved, and this approximation can be merely justified by their migration process along the coasts of Oman Sea and Persian Gulf. Therefore, the assessment of distribution patterns of 20 haplotypes in the constructed phylogenetic tree using mtDNA D-Loop sequences ascertained that no significant clustering according to the sampling sites was concluded.
\end{abstract}

Keywords Phylogeny $\cdot$ mtDNA D-loop $\cdot$ Persian Gulf $\cdot$ Oman Sea $\cdot$ Arabian Sea $\cdot$ Scomberomorus commerson

\section{Introduction}

The tunas pertaining to the family Scombridae, contain an invaluable group of fishes. The Narrow-barred Spanish mackerel, Scomberomorus commerson (Lacepede 1800), is one of the most important commercial pelagic and migratory species (Al-Hosni and Siddeek 1999) which exploited in the Persian Gulf, Oman Sea

A. Mansourkiaei · P. G. Mostafavi (凶) - S. M. R. Fatemi

Department of Marine Biology, Science and Research Branch, Islamic Azad University, Tehran, Iran

e-mail: gh.mostafavi@gmail.com

A. Mansourkiaei

e-mail: ana_kiaei@yahoo.com

F. Kaymaram

Iranian Fisheries Science Research Institute (IFSRI), Agricultural Research, Education and Extension Organization

(AREEO), Tehran, Iran

A. Nazemi

Department of Genetic, Tonekabon Branch, Islamic Azad University, Tonekabon, Iran 
and Arabian Sea. This fish belongs to the family of Scombridae with 15 genera and 49 species (Collette and Nauen 1983). It is an epipelagic species, with the depth range between 10 and $70 \mathrm{~m}$ (Pauly et al. 1996), distributed throughout the coastal tropical waters of the Indo-Pacific: Red Sea and South Africa to Southeast Asia, north to China and Japan and south to southeast Australia, and to Fiji (Kailola et al. 1993). Southeast Atlantic, the Narrow-barred Spanish mackerel, customarily named Kingfish. This highly valued pelagic fish, caught seasonally along the Iranian coastal waters of the Persian Gulf, Oman Sea and Arabian Sea. Seasonally, peak of the fishing is among October and June and their migratory movement from Arabian Sea towards the Persian Gulf, in September and in the opposite direction, around April has been attached with this seasonality occurrence (FAO 1989).

Fish population genetic structure has assimilated sizeable affinity, not only because of prime interest in evolution of biotic (Tudela et al. 1999), but also because of its prominence for fisheries management (RoldanRuizi et al. 2000). Management strategies are enabled to be planned by Biological and ecological knowledge about natural resources, particularly in species with conspicuous conservation or commercial status. Sound perceptions into issue of inter and intraspecific population structuring can be procured with genetic analyses (Avise 1994). Molecular biology procedure have become significantly substantial in ascertaining fish stock structure and sizeable rise in the count of forthcoming molecular markers for genetic analyses of population construction for the late three decades with allozyme, nuclear DNA (nDNA) and mitochondrial DNA (mtDNA) have been deployed for this intent. These markers have been exerted for population genetic analyses of manifold tuna species and each of them has their own profitability (allozyme: Ward et al. 1994; mtDNA: Menezes et al. 2006; nDNA: Menezes et al. 2008). mtDNA is haploid and maternally inherited and has an expeditious revolution amount in comparison to nDNA and hence obtains higher gradation of genetic dissociation than allozyme.

Mitochondrial DNA (mtDNA) is customarily applied in population genetic investigation. Manifold special characteristics such as unavailability of introns, maternal inheritance, high rate of mutation, nonattendance of recombination possibility are demonstrated by mitochondrial DNA (Irwin et al. 1991; Pesole et al. 1999). Parallels among mtDNA D-loop region's sequences have been exerted comprehensively to assess genetic differentiation and phylogenetic relationships among individuals and populations of Fishes (Loftus et al. 1994; Bradley et al. 1996; Mannen et al. 1998; Kikkawa et al. 2003).

High resolution melting analysis (HRMA) is a highly sensitive closed-tube genotyping method used primarily in clinical studies. As the method is rapid, inexpensive and amenable to high throughput, its

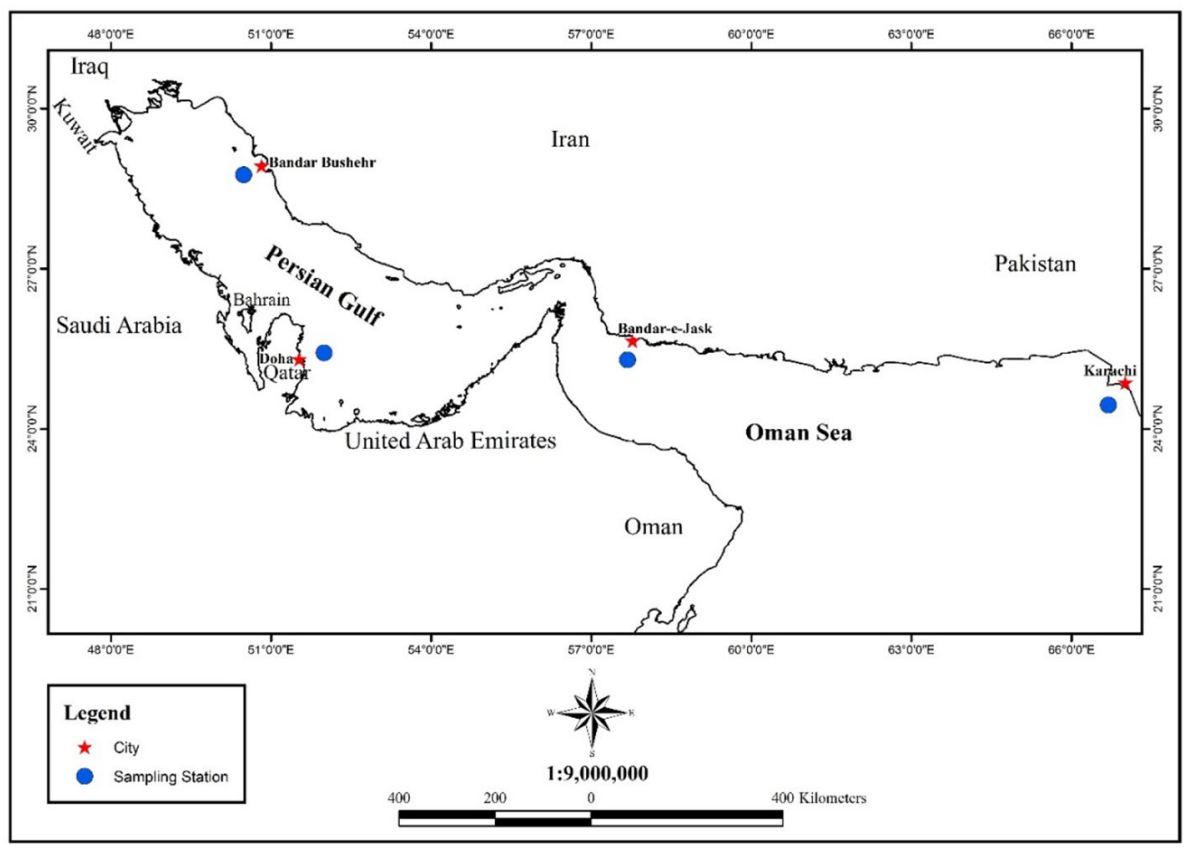

Fig. 1 Four sampling sites of S. commerson in Persian Gulf, Oman Sea and Arabian Sea 
applicability to population studies has been investigated in populations of swordfish, Xiphias gladius. Thus, HRMA is a powerful genotyping tool to study wild populations (Smith and Bremer 2010).

An applicable management of stock structure is needed for sustainable exploitation of fishes. The current study strives to examine the forthcoming phylogenetic relationships of $S$. commerson among four sites located in Persian Gulf, Oman Sea and Arabian Sea.

\section{Material and method}

\section{Sampling}

During this research, a total of $100 \mathrm{~S}$. Commerson specimens were collected by gillnet operating at four regions: Bushehr and Doha in Persian Gulf, Jask in Oman Sea and Karachi in Arabian Sea. Specimens were caught during the October of 2013 to May 2014 in the coastal waters of the Persian Gulf, Oman Sea and Arabian Sea (Fig. 1). Part of dorsal fin were snipped and transferred to micro-tubes containing ethanol (Menezes et al. 2012) and stored at $-20^{\circ} \mathrm{C}$ till further processing.

DNA extraction and amplification

Total genomic DNA was extracted using High Pure PCR Template preparation Kit Roche Cat. no. 11796828001. Electrophoresis method was used to determine the quality and quantity of extracted DNA. DNAs were electrophoresed through $1 \%$ agarose gel which stained with gel red.

\section{Amplification and sequencing}

The mtDNA D-loop region was amplified using the primer set designed by Meneses. (Menezes et al. 2006). The primer sequences were as follows: (forward primer) $5^{\prime}$-CCGGACGTCGGAGGTTAAAAT-3' and (reverse primer) 5'-AGGAACCAAATGCCAGGAATA-3' (Primers manufacturer: Gen fanavaran Tehran, Iran). Polymerase Chain Reaction (PCR) was performed in a $25 \mu \mathrm{l}$ reaction mixture containing $50 \mathrm{ng}$ of genomic DNA, 10X Reaction Buffer (Tris $50 \mathrm{mM}, \mathrm{KCl} 10 \mathrm{mM}$ ) $1.5 \mathrm{mM} \mathrm{MgCl} 2,0.2 \mathrm{mM}$ dNTPs, $0.3 \mathrm{pM}$ of each primer and 1.5 units of Taq DNA Polymerase, SYTO 9. The reaction profiles contained an preliminary denaturation at $94{ }^{\circ} \mathrm{C}$ for $5 \mathrm{~min}$, prosecuted by 30 cycles, each comprising of $30 \mathrm{~s}$ denaturation at $94{ }^{\circ} \mathrm{C}, 54 \mathrm{~s}$ primer annealing at $56{ }^{\circ} \mathrm{C}, 30 \mathrm{~s}$ extension at $72{ }^{\circ} \mathrm{C}$, and then at the end of reaction 5 min extension at $72{ }^{\circ} \mathrm{C}$. HRM ramps from $65{ }^{\circ} \mathrm{C}$ to $90{ }^{\circ} \mathrm{C}$ rise by $0.1{ }^{\circ} \mathrm{C}$ each step and wait for $90 \mathrm{~s}$ of pre-melt conditioning on first step and then wait for $5 \mathrm{~s}$ for each step afterwards. PCR products were screened through electrophoresis, Hereupon, PCR products were electrophoresed via $2.0 \%$ (wt/vol) agarose gel which were stained with gel red.

Out of 100 Specimens, 20 were recognized as representative specimens of each group and a renewed PCR was performed to be sent to sequence.

Statistical analysis

All the sequences were checked and amended using the BioEdit 7.0 software. CLC Sequence Viewer 6.5.2 was exerted to align sequences. MEGA 6.06 program (Tamura et al. 2013) was employed to generate phylogenetic tree.

\section{Results}

Around 443-bp fragment of mitochondrial DNA D-Loop region was sequenced in forward direction for 20 individuals of S. commerson (from four sampling sites located in the Persian Gulf (Bushehr and Doha), Oman Sea (Jask) and Arabian Sea (Karachi) as representative specimens of each group designated according to HRM-Real Time PCR. 
Due to High Resolution Melting Analyses (A segregation technique using Melting point of DNA) the Rotor Gene 6000 (Corbett) 20 samples were designated to be sequenced only in forward direction. Representative specimens were illustrated in Table 1. A renewed PCR reaction was performed for representative specimens to be sent for sequencing. The PCR products were screened through electrophoresis (Fig. 2). Subsequently, PCR products so as to do sequencing, were sent to Bioneer Corporation, which is located in South Korea.

All the sequences were verified and revised using the BioEdit7.0 software. CLC Sequence Viewer 6.5.2 was exerted to align sequences and the alignments for the representative specimens were represented in Fig. 3. Just Part of the alignments which showed the biggest changes have been illustrated. MEGA 6.06 program was used to generate phylogenetic tree. Accession numbers of the deposited sequences in GenBank are as follows: S15K, S4J, S1D, S4B, respectively, (LC101261.1- LC101262.1- LC101263.1-LC101264.1), S17K (LC101268.1), S3D (LC101270.1), and the others are in the process of transferring.

Evolutionary relationships

The evolutionary relationships of 20 sequences of $S$. commerson were inferred using the neighbor joining method (NJ: Saitou and Nei 1987). The bootstrap consensus tree inferred from 1000 replicates (Felsenstein 1985). The evolutionary distances were computed using the Kimura 2-parameter method (Kimura 1980) by

Table 1 Indicating representative specimens on the strength of HRM-Real Time PCR

\begin{tabular}{|c|c|c|c|c|c|c|c|c|c|}
\hline \multicolumn{10}{|c|}{ Samples' banding using HRM-real time PCR } \\
\hline Var 1 & Var 2 & Var 3 & Var 4 & Var 5 & Var 6 & Var 7 & Var 8 & Var 9 & Var 10 \\
\hline $\mathrm{S}_{1} \mathrm{D}$ & $\mathrm{S}_{3} \mathrm{D}$ & $\mathrm{S}_{4} \mathrm{D}$ & $\mathrm{S}_{9} \mathrm{D}$ & $\mathrm{S}_{18} \mathrm{D}$ & $\mathrm{S}_{21} \mathrm{D}$ & $\mathrm{S}_{1} \mathrm{~B}$ & $\mathrm{~S}_{4} \mathrm{~B}$ & $\mathrm{~S}_{8} \mathrm{~B}$ & $\mathrm{~S}_{9} \mathrm{~B}$ \\
\hline $\mathrm{S}_{2} \mathrm{D}$ & $\mathrm{S}_{7} \mathrm{D}$ & $\mathrm{S}_{11} \mathrm{D}$ & $\mathrm{S}_{15} \mathrm{D}$ & $\mathrm{S}_{1} \mathrm{~J}$ & $\mathrm{~S}_{2} \mathrm{~B}$ & $\mathrm{~S}_{3} \mathrm{~B}$ & $\mathrm{~S}_{6} \mathrm{~B}$ & & \\
\hline $\mathrm{S}_{5} \mathrm{D}$ & $\mathrm{S}_{10} \mathrm{D}$ & $\mathrm{S}_{12} \mathrm{D}$ & $\mathrm{S}_{16} \mathrm{D}$ & $\mathrm{S}_{14} \mathrm{~J}$ & $\mathrm{~S}_{5} \mathrm{~B}$ & $\mathrm{~S}_{8} \mathrm{~K}$ & $\mathrm{~S}_{11} \mathrm{~B}$ & & \\
\hline $\mathrm{S}_{6} \mathrm{D}$ & $\mathrm{S}_{13} \mathrm{D}$ & $\mathrm{S}_{14} \mathrm{D}$ & $\mathrm{S}_{17} \mathrm{D}$ & $\mathrm{S}_{26} \mathrm{~J}$ & $\mathrm{~S}_{7} \mathrm{~B}$ & $\mathrm{~S}_{9} \mathrm{~K}$ & $\mathrm{~S}_{19} \mathrm{~B}$ & & \\
\hline $\mathrm{S}_{8} \mathrm{D}$ & $\mathrm{S}_{22} \mathrm{D}$ & $\mathrm{S}_{24} \mathrm{D}$ & $\mathrm{S}_{19} \mathrm{D}$ & & $\mathrm{S}_{10} \mathrm{~B}$ & $\mathrm{~S}_{16} \mathrm{~K}$ & & & \\
\hline \multirow[t]{13}{*}{$\mathrm{S}_{20} \mathrm{D}$} & $\mathrm{S}_{21} \mathrm{~B}$ & $\mathrm{~S}_{25} \mathrm{D}$ & $\mathrm{S}_{23} \mathrm{D}$ & & $\mathrm{S}_{12} \mathrm{~B}$ & $\mathrm{~S}_{18} \mathrm{~K}$ & & & \\
\hline & $\mathrm{S}_{3} \mathrm{~K}$ & & $\mathrm{~S}_{14} \mathrm{~B}$ & & $\mathrm{~S}_{13} \mathrm{~B}$ & & & & \\
\hline & $\mathrm{S}_{7} \mathrm{~K}$ & & $\mathrm{~S}_{20} \mathrm{~B}$ & & $\mathrm{~S}_{15} \mathrm{~B}$ & & & & \\
\hline & $\mathrm{S}_{14} \mathrm{~K}$ & & $\mathrm{~S}_{22} \mathrm{~B}$ & & $\mathrm{~S}_{16} \mathrm{~B}$ & & & & \\
\hline & $\mathrm{S}_{19} \mathrm{~K}$ & & $\mathrm{~S}_{25} \mathrm{~B}$ & & $\mathrm{~S}_{28} \mathrm{~B}$ & & & & \\
\hline & $\mathrm{S}_{29} \mathrm{~K}$ & & $\mathrm{~S}_{26} \mathrm{~B}$ & & & & & & \\
\hline & & & $\mathrm{S}_{31} \mathrm{~B}$ & & & & & & \\
\hline & & & $\mathrm{S}_{11} \mathrm{~K}$ & & & & & & \\
\hline & & & $\mathrm{S}_{12} \mathrm{~K}$ & & & & & & \\
\hline & & & $\mathrm{S}_{24} \mathrm{~K}$ & & & & & & \\
\hline & & & $\mathrm{S}_{25} \mathrm{~K}$ & & & & & & \\
\hline & & & $\mathrm{S}_{28} \mathrm{~K}$ & & & & & & \\
\hline & & & $\mathrm{S}_{4} \mathrm{~K}$ & & & & & & \\
\hline Var 11 & Var 12 & Var 13 & Var 14 & Var 15 & Var 16 & Var 17 & Var 18 & Var 19 & Var 20 \\
\hline $\mathrm{S}_{2} \mathrm{~K}$ & $\mathrm{~S}_{15} \mathrm{~K}$ & $\mathrm{~S}_{17} \mathrm{~K}$ & $\mathrm{~S}_{4} \mathrm{~J}$ & $\mathrm{~S}_{7} \mathrm{~J}$ & $\mathrm{~S}_{12} \mathrm{~J}$ & $\mathrm{~S}_{10} \mathrm{~J}$ & $\mathrm{~S}_{13} \mathrm{~J}$ & $\mathrm{~S}_{15} \mathrm{~J}$ & $\mathrm{~S}_{17} \mathrm{~J}$ \\
\hline $\mathrm{S}_{23} \mathrm{~K}$ & $\mathrm{~S}_{21} \mathrm{~K}$ & $\mathrm{~S}_{22} \mathrm{~K}$ & $\mathrm{~S}_{6} \mathrm{~J}$ & $\mathrm{~S}_{28} \mathrm{~J}$ & $\mathrm{~S}_{21} \mathrm{~J}$ & $\mathrm{~S}_{16} \mathrm{~J}$ & & & \\
\hline $\mathrm{S}_{26} \mathrm{~K}$ & $\mathrm{~S}_{27} \mathrm{~K}$ & $\mathrm{~S}_{31} \mathrm{~K}$ & & $\mathrm{~S}_{17} \mathrm{~B}$ & $\mathrm{~S}_{23} \mathrm{~J}$ & $\mathrm{~S}_{18} \mathrm{~J}$ & & & \\
\hline \multirow[t]{5}{*}{$\mathrm{S}_{10} \mathrm{~K}$} & $\mathrm{~S}_{30} \mathrm{~K}$ & $\mathrm{~S}_{20} \mathrm{~J}$ & & & $\mathrm{~S}_{24} \mathrm{~J}$ & $\mathrm{~S}_{25} \mathrm{~J}$ & & & \\
\hline & & $\mathrm{S}_{11} \mathrm{~J}$ & & & & $\mathrm{~S}_{27} \mathrm{~J}$ & & & \\
\hline & & & & & & $\mathrm{S}_{31} \mathrm{~J}$ & & & \\
\hline & & & & & & $\mathrm{S}_{32} \mathrm{~J}$ & & & \\
\hline & & & & & & $\mathrm{S}_{33} \mathrm{~J}$ & & & \\
\hline
\end{tabular}




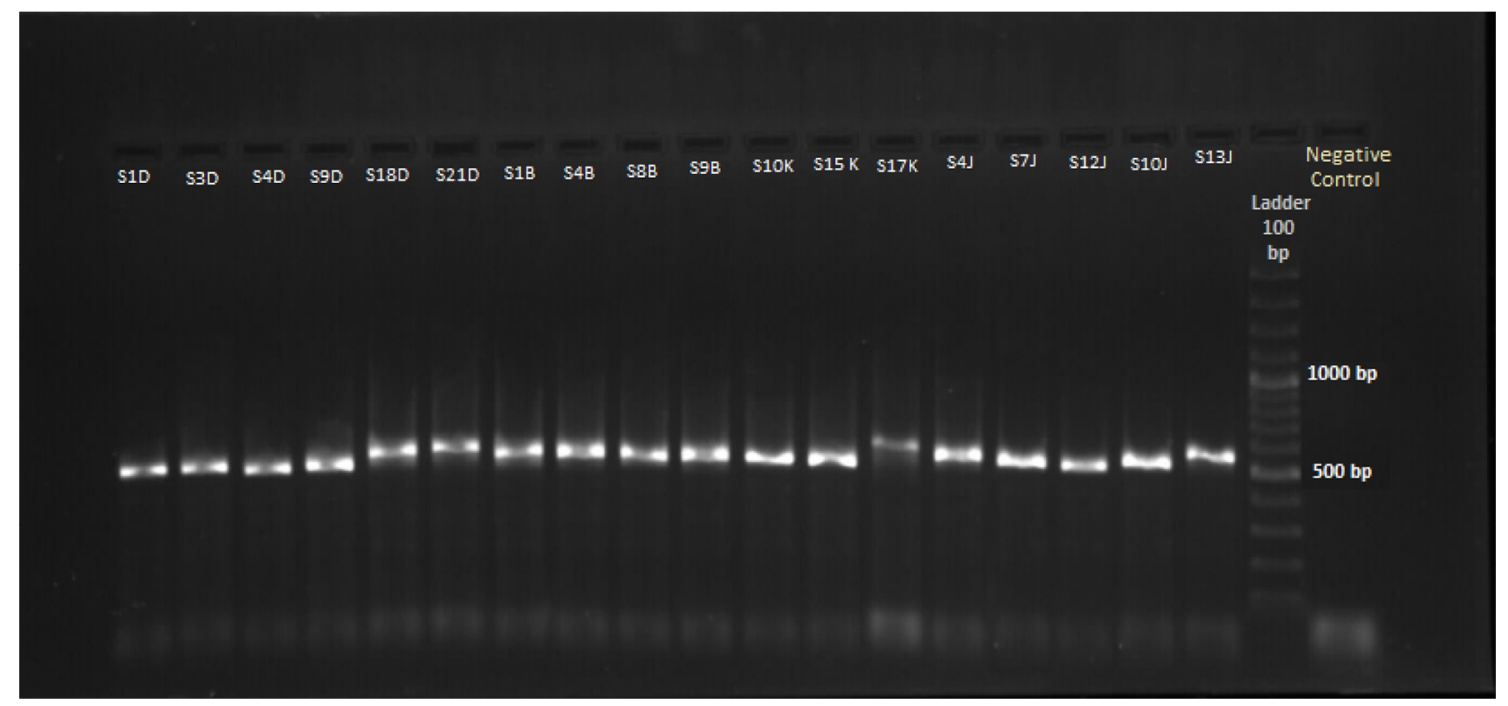

Fig. 2 Amplified PCR products of $S$. commerson (from 20 samples, just 18 samples were demonstrated and the two others were good as well). $S$ sample, $D$ Doha, $B$ Bushehr, $K$ Karachi, $J$ Jask

means of MEGA 6.06 program and are in the units of the number of base substitutions per site. The analysis involved 21 nucleotide sequences. The neighbor joining (NJ) phylogenetic tree was presented in Fig. 4.

Nucleotide composition

The percentage-wise nucleotide composition of $S$. commerson has been computed and are indicated in Table 2 and the same also plotted in Fig. 5. The mean composition was 'A' $34.5 \%$, ' $T$ ' $32.1 \%$, 'G' $12.7 \%$ and 'C' $20.7 \%$. The value of 'AT' (66.6\%) is much higher than 'GC' $(33.4 \%)$. Between these regions, Doha demonstrated the highest 'AT' content of $67 \%$ and lowest 'GC' content $33.0 \%$.

\section{$\mathrm{K}_{2} \mathrm{P}$ distances}

The Kimura 2 Parameter $\left(\mathrm{K}_{2} \mathrm{P}\right)$ distances were screened to show the intra and inter-specific variations of species. Estimates of average evolutionary divergence over sequence pairs within groups were shown in Table 3. The number of base substitutions per site from averaging over all sequence pairs within each group is demonstrated and standard errors are indicated as well. Analyses were conducted using the Kimura 2-parameter model. Likewise, the number of base substitutions per site from averaging over all sequence pairs between groups is shown in Table 4.

Estimates of evolutionary divergence between sequences are presented in Fig. 6. The number of base substitutions per site between sequences is shown. There were a total of 401 positions in the final dataset.

Figures in Table 5 show the convergence and divergence between specimens. The Nearest distances are seen between S9D and S3D; in other word, they completely are similar together (pairwise distance calculation $=0$ ), the next nearest distances are seen between S4B and S3D, S4B and S9D (pairwise distance calculation $=0.003$ ), S10J and S15K (pairwise distance calculation $=0.005$ ), S18D and S1D, S10J and S18D, S10J and S4D (pairwise distance calculation $=0.008$ ). Likewise, farthest distance are seen between S4B and S18D, S4J and S8B, S4J and S21D (pairwise distance calculation $=00.049$ ).

\section{Discussion}

A few studies have been done on phylogeny of tuna species as well. Coastal tunas (Thunnus tonggol, Euthynnus affinis, Auxis Thazard, Auxis rochei) were inferred through mitochondrial DNA sequences in the Cytochrome c oxidase I (COI) gene. Analyzing phylogenetic relationships of these coastal tunas using NJ 


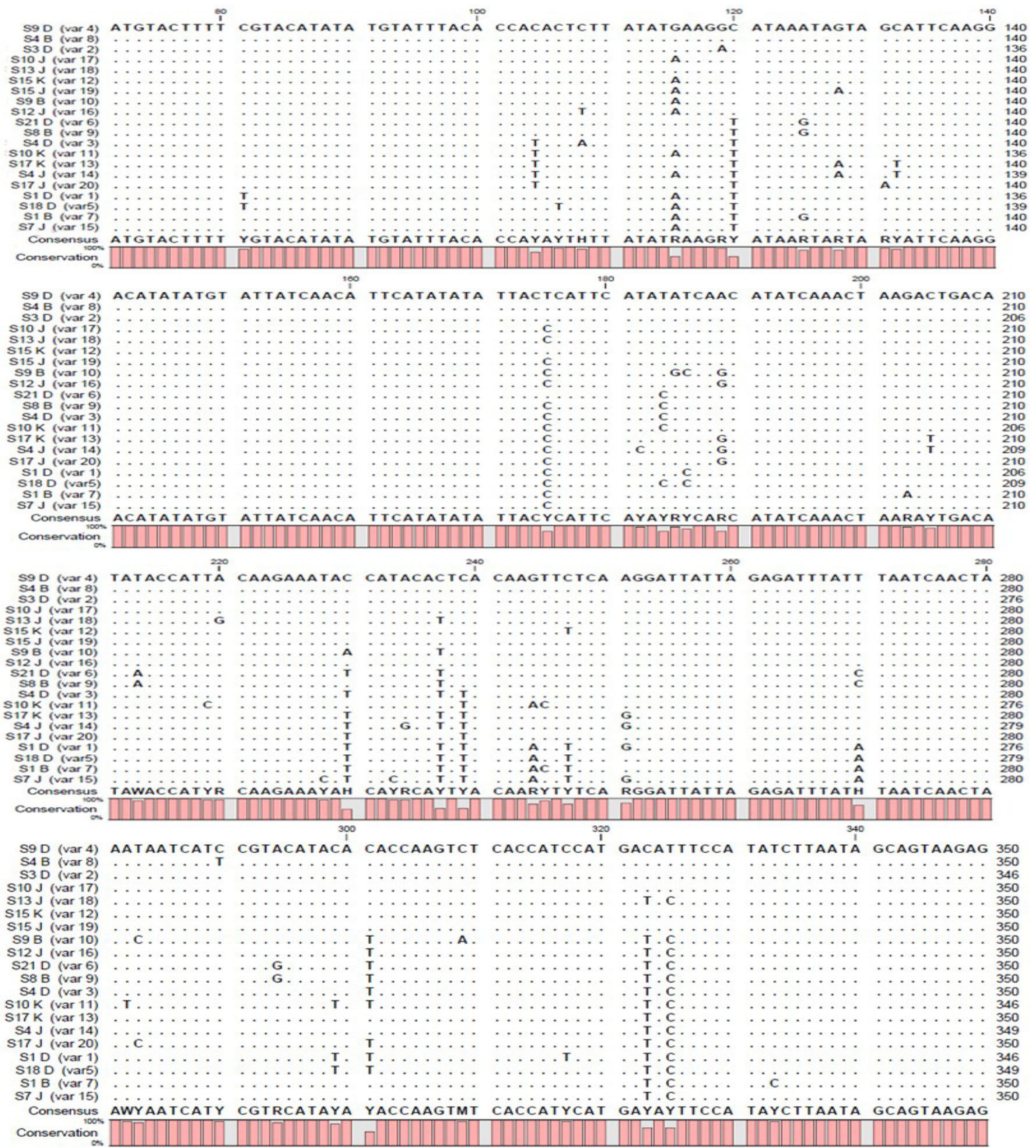

Fig. 3 The alignment of the representative specimens using CLC Sequence Viewer 6.5.2 [IUPAC signs ( $R$ A/G (purine), $Y$ C/T (pyrimidine), $M \mathrm{~A} / \mathrm{C}, W \mathrm{~A} / \mathrm{T}, S \mathrm{C} / \mathrm{G}, K \mathrm{G} / \mathrm{T}, B \mathrm{C} / \mathrm{G} / \mathrm{T}, D \mathrm{~A} / \mathrm{G} / \mathrm{T}, H \mathrm{~A} / \mathrm{C} / \mathrm{T}, V \mathrm{~A} / \mathrm{C} / \mathrm{G}, N \mathrm{~A} / \mathrm{C} / \mathrm{G} / \mathrm{T})]$. Var variation, $S$ sample, $D$ Doha, $B$ Bushehr, $K$ Karachi, $J$ Jask

method indicated shallow intra-specific and deep inter-specific divergence. (Mudumala et al. 2011). A more comprehensive survey was done on S. commerson. The genetic composition of this species across the IndoWest Pacific range using control-region sequences (including previously published datasets), cytochrome-b gene partial sequences, and eighth microsatellite loci, to further explore its phylogeographic structure. All haplotypes sampled from the Indo-Malay-Papua archipelago (IMPA) and the southwestern Pacific coalesced into a clade (clade II) that was deeply separated from a clade grouping all haplotypes from the Persian Gulf and Oman Sea (clade I), and such a high level of genetic divergence suggested the occurrence of two sister species (Fauvelot and Borsa 2012). The other survey illustrated that S. commerson being a single genetic stock in the ROPME sea area (Persian Gulf, Oman Sea and Arabian Sea) using restriction fragment length polymorphism (RFLP) (Hoolihan et al. 2006). And also investigation on genetic differentiation of S. commerson 


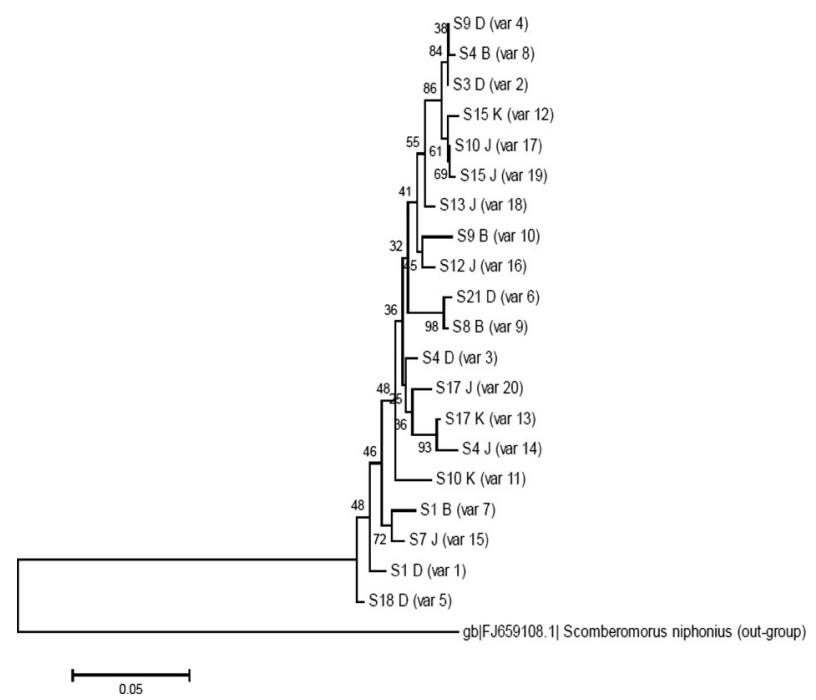

Fig. 4 Neighbor-joining tree of $S$. commerson mitochondrial DNA D-Loop region using MEGA 6.06 program (Var variation, $S$ sample, $D$ Doha, $B$ Bushehr, $K$ Karachi, $J$ Jask). GenBank accession numbers: S15K, S4J, S1D, S4B (LC101261.1-LC101264.1), S17K (LC101268.1), S3D (LC101270.1), Out-group (FJ659108.1)

Table 2 Percentage-wise nucleotide composition of $S$. commerson in four sites (total no: total number of nucleotides)

\begin{tabular}{llllllll}
\hline Name of the sites & $\mathrm{T}(\%)$ & $\mathrm{C}(\%)$ & $\mathrm{A}(\%)$ & $\mathrm{G}(\%)$ & Total no & AT $(\%)$ & GC $(\%)$ \\
\hline Doha & 32.3 & 20.3 & 34.6 & 12.7 & 441.2 & 67.0 & 33.0 \\
Bushehr & 31.8 & 21.0 & 34.3 & 12.9 & 445.0 & 66.2 & 33.8 \\
Karachi & 32.3 & 20.5 & 34.6 & 12.6 & 439.7 & 66.9 & 33.1 \\
Jask & 32.0 & 20.9 & 34.3 & 12.7 & 445.3 & 66.3 & 33.7 \\
Total & 32.1 & 20.7 & 34.5 & 12.7 & 443.2 & 66.6 & 33.4 \\
\hline
\end{tabular}

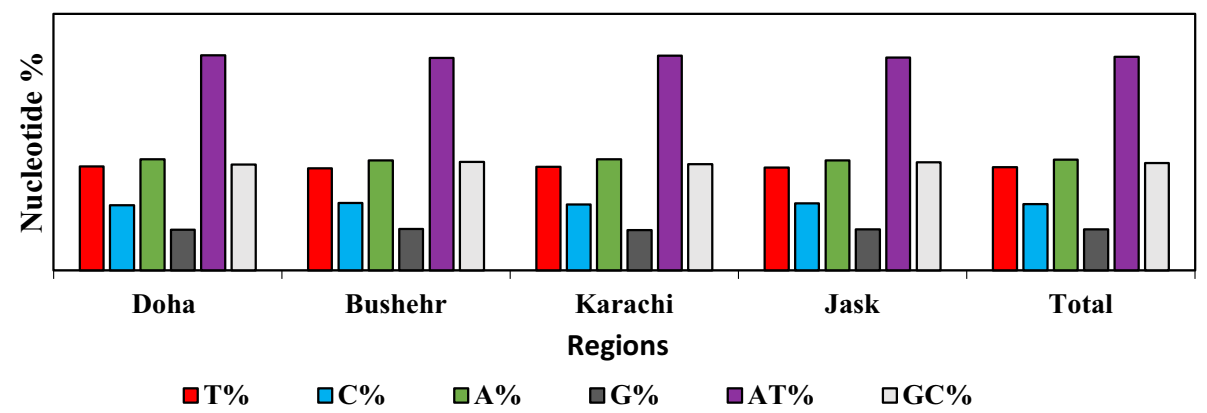

Fig. 5 Percentage-wise nucleotide composition of S. commerson for four sites in the Persian Gulf, Oman Sea and Arabian Sea computed through MEGA 6.06 program

Table $3 \mathrm{~K}_{2} \mathrm{P}$ distances of $S$. commerson (within group distance), estimates of average evolutionary divergence over sequence pairs

\begin{tabular}{lll}
\hline S. commerson & Distance $(D)$ & Standard error (SE) \\
\hline Doha & 0.030 & 0.006 \\
Bushehr & 0.036 & 0.007 \\
Karachi & 0.038 & 0.008 \\
Jask & 0.028 & 0.005 \\
\hline
\end{tabular}


Table $4 \mathrm{~K}_{2} \mathrm{P}$ distances of $S$. commerson (between groups), the number of base substitutions per site from averaging over all sequence pairs, between groups

\begin{tabular}{|c|c|c|c|c|}
\hline & Doha & Bushehr & Karachi & Jask \\
\hline \multicolumn{5}{|l|}{ Doha } \\
\hline Bushehr & 0.030 & & & \\
\hline Karachi & 0.031 & 0.033 & & \\
\hline Jask & 0.030 & 0.030 & 0.028 & \\
\hline
\end{tabular}

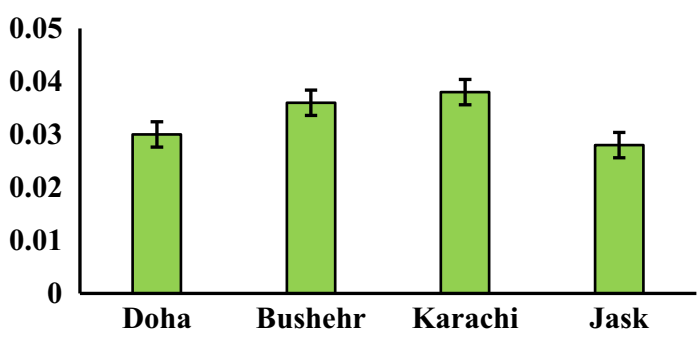

Fig. 6 Graphical presentation of $\mathrm{K}_{2} \mathrm{P}$ distances of $S$. commerson for four sites (within group distance), estimates of average evolutionary divergence over sequence pairs

stocks using microsatellite markers in the Persian Gulf demonstrated that adopting a single stock model so regional shared management could probably be appropriate for sustainable long-term use of this important resource in the Persian Gulf (Abedi et al. 2012).

There have been a number of studies on Genetic Structure of tuna species based on mitochondrial DNA D-Loop. Genetic stock structure of Frigate Tuna (Auxis thazard) along Indian coast based on PCR-RFLP analyses of mtDNA D-Loop region have been surveyed and two genetic stocks of Frigate Tuna were suggested across the coastal waters of India (Kumar et al. 2012). Likewise, the genetic divergence between Auxis thazard and Auxis rochei was surveyed based on PCR-RFLP analysis of mtDNA D-Loop region and high level of genetic divergence was observed (Kumar et al. 2014). Population genetic structure of Skipjack tuna (Katsuwonus pelamis) from the Indian coast using sequence analysis of the mitochondrial DNA D-Loop region was examined and analysis of molecular variance showed significant genetic variation among four groups and the phylogenetic analysis of the mtDNA sequence data demonstrated the occurrence of four genetically differentiated groups of K. pelamis (Menezes et al. 2012). Another survey was done along the Indian coast based on mitochondrial DNA analysis and three stocks of yellowfin tuna were detected so the null hypothesis of single panmictic population of this fish was rejected (Kunal et al. 2013). Microsatellite and mitochondrial DNA analyses of Thunnus thynnus thynnus population structure in the eastern basin of the Mediterranean Sea showed that the possibility of a genetically discrete population (Carlsson et al. 2004). The other study, demonstration of close genetic similarity of Atlantic and Pacific skipjack tuna (katsuwonus pelamis) with restriction endonuclease analysis of mtDNA, was done and the results represented that since the uplift of the Panama land bridge about 3.1 milion years ago, there has been continued genetic contact between Atlantic and Pacific tuna, presumably through the Southern Ocean (Grave et al. 1984). Mitochondrial DNA analysis reveals a single stock of Auxis thazard in the northern coastal waters of Tanzania from two geographically separate locations (Johnson et al. 2015).

Mitochondrial DNA D-Loop region sequencing which is used in evolutionary and phylogenetic relationships among $S$. commerson species indicated how far or close they are. The assessment of distribution patterns of 20 sequences in the constructed phylogenetic tree using mtDNA D-Loop sequences ascertained that no significant clustering according to the sampled sites was detected. Hereupon, highest similarity was observed among the species at four sites in the Persian Gulf, Oman Sea and Arabian Sea. The pairwise distance calculations, listed figures in Table 5, represented the proximity to or remoteness of each other. Thus, high genetic distance and low genetic distance between and into sampled sites simultaneously were shown, So, mixed population were concluded. 


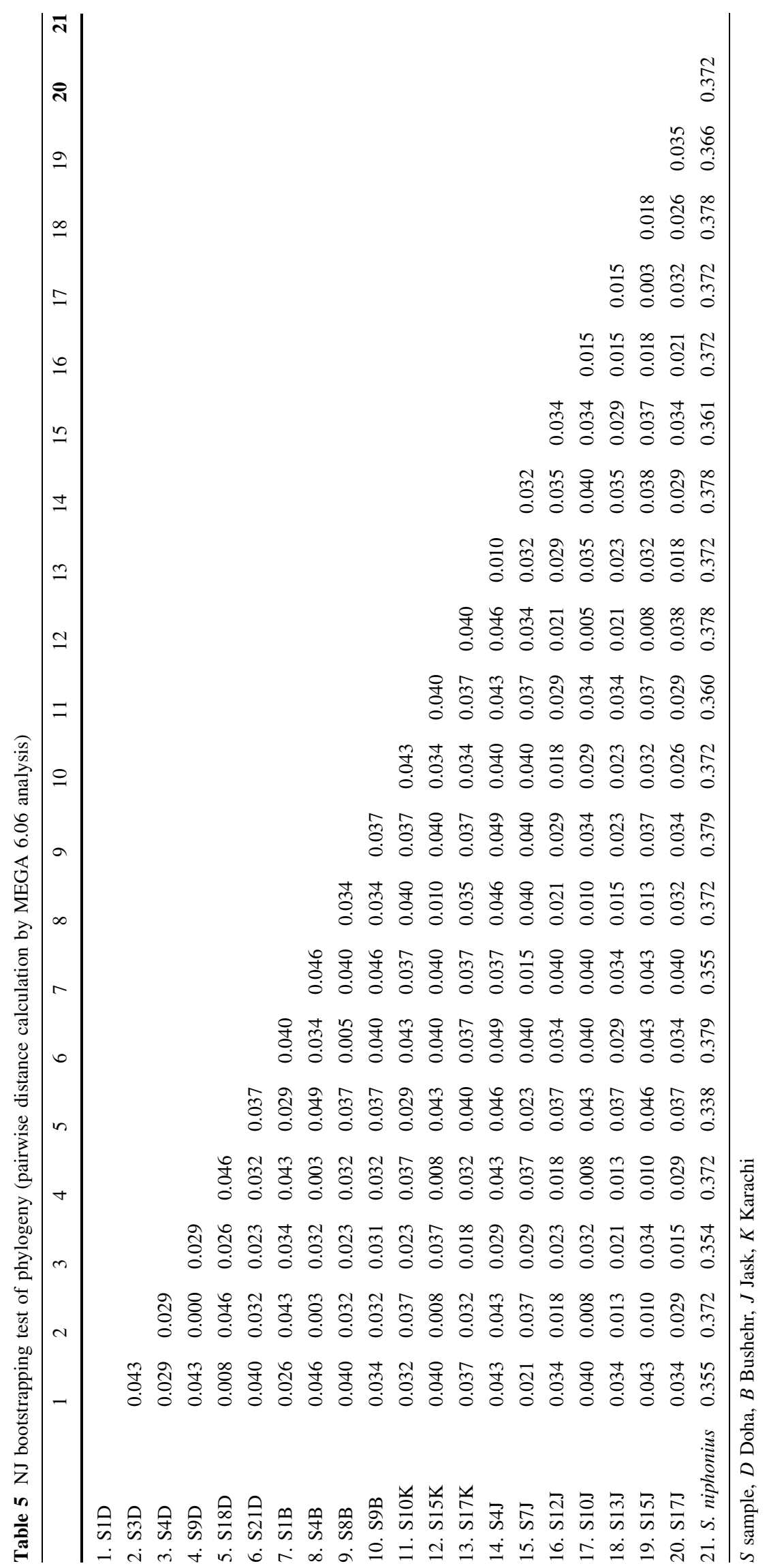


Lowest and highest divergence within populations of $S$. commerson were perceived, respectively in Jask (0.028) and Karachi (0.038). furthermore, lowest and highest divergence between sites were seen in Jask and Karachi (0.028), Karachi and Bushehr (0.033), although there were not much discrepancy between them, this low level of differentiations may happen as a result of geographical distance. Since, there is long distance between Karachi (located in Pakistan-Arabian Sea) and Bushehr (located in the northern extremity of the Persian Gulf) in comparison with Jask (located in Oman Sea) and Karachi(situated in Pakistan-Arabian Sea).So, they are far away enough that this figures could be justified, as, it is displayed in NJ tree.

Another analysis, alignment, has been made possible by DNA sequencing. The alignment demonstrated single nucleotide polymorphisms. Analyses of alignment among four sites in the Persian Gulf, Oman Sea and Arabian Sea using CLC-viewer program showed Single Nucleotide Polymorphisms (SNPs).The alignments showed that S4B and S9D showed merely one nucleotide difference (SNP). And the next haplotype, S3D demonstrated two SNPs and so on. The differences (convergence and divergence values) between haplotypes were proved by these observed SNPs. The lowest and highest SNPs were, respectively observed in S4B and S18D (one and eighteen single nucleotide mutations, respectively).

The neighbor joining (NJ) phylogenetic tree was constructed using the MEGA 6.06 program with a Kimura 2 parameter model and the bootstrap value 1000. Simultaneously, an out-group was applied for generating phylogenetic tree as it is showed in Fig. 4. As NJ tree demonstrated that all populations were similar and close together and they indicated one stock in four sites. As pairwise calculation distances represented in Table 5 a high degree of similarity were perceived among S. commerson from the Persian Gulf, Oman Sea and Arabian Sea, thereafter, having one stock structure of S. commerson in four sites were proved. And this approximation can be merely justified by their migration process.

Corresponding to the current study, investigations on S. commerson represented a single genetic stock in the ROPME sea area (Hoolihan et al. 2006); similarly, observed genetic differentiation of $S$. commerson at four sampled sites in the Persian Gulf revealed a single stock model (Abedi et al. 2012). Transacted investigations showed genetic isolation and genetic structure of S. commerson. These results were analogous to the current investigation. Hereupon, a single Panmictic stock of $S$. commerson was proved by different markers through these inquiries; so, we have to be warned to care about this important stock in the Persian Gulf and Oman Sea.

\section{Conclusion}

In the present study, the first analysis of S. commerson phylogenetic relationship in the Persian Gulf, Oman Sea and Arabian Sea was carried out based on mtDNA D-loop region among the four sites. The results represented a genetic connectivity among four sampled sites through high level of similarity between sites. In general, marine species have low levels of genetic differentiation for several reasons: (1) the overall absence of clear barriers to distribution in the marine environment effectually reduces heterogeneity between populations; (2) a small number of migrants per generation are adequate to remove genetic differentiation; (3) marine species have high fecundities and dispersal abilities (Waples 1998).these are particularly true of highly migratory vagile species with planktonic larvae such as members of the genus Scomberomorus (Broughton et al. 2002; Buonaccorsi et al.1999).

The point is that, this fish is considered as an epipelagic and migratory species; hence, the high similarity among four sampled sites could be justified. Demonstrated single Panmictic stock via phylogenetic analysis can warn us to care about this notable stock in these sites. So, a parade of strategies should be considered for sustainable exploitation of this important resource in the Persian Gulf, Oman Sea and Arabian Sea.

Acknowledgments We are grateful to Mohammad Eskandari and Mohammad Tagi Azhir and Abolhasan Rezaei, Mehrnoush Norozi, Ahmad Gasemi, fereydoun Chakmehdooz and the staff of the laboratory in Islamic Azad university of Tonekabon and Tehran.

Open Access This article is distributed under the terms of the Creative Commons Attribution 4.0 International License (http:// creativecommons.org/licenses/by/4.0/), which permits unrestricted use, distribution, and reproduction in any medium, provided you give appropriate credit to the original author(s) and the source, provide a link to the Creative Commons license, and indicate if changes were made. 


\section{References}

Abedi E, Zolgharnein H, Salari MA, Qasemi A (2012) Genetic differentiation of narrow-barred Spanish mackerel (Scomberomorus commerson) stocks using microsatellite markers in Persian Gulf. Am Eurasian J Agri Environ Sci 12(10):1305-1310

Al-Hosni AH, Siddeek SM (1999) Growth and mortality of the narrow-barred Spanish mackerel, Scomberomorus commerson (Lacepede), in Omani waters. Fish Man Ecol 6:145-160

Avise JC (1994) Molecular markers, natural history, and evolution. Chapman \& Hall, New York, p 511

Bradley L, Wainstock D, Sive H (1996) Positive and negative signals modulate formation of the Xenopus cementgland. Development 122:2739-2750

Broughton RE, Stewart LB, Gold JR (2002) Microsatellite variation suggests substantial gene flow between king mackerel (Scomberomorus cavalla) in the western Atlantic Ocean and Gulf of Mexico. Fish Res 54:305-316

Buonaccorsi VP, Reece KS, Morgan LW, Graves JE (1999) Geographic distribution of molecular variance within the blue marlin (Makaira nigricans): a hierarchical analysis of allozyme, single-copy nuclear DNA and mitochondrial DNA markers. Evolution 53:568-579

Carlsson J, Mcdowell JR, Diaz-Jaimes P, Carlsson JEL, Boles SB, Gold JR, Graves E (2004) Microsatellite and mitochondrial DNA analyses of Atlantic bluefin tuna (Thunnus thynnus thynnus) population structure in Mediterranean Sea. Mol Ecol 13:3345-3356

Collette BB, Nauen CE (1983) FAO species catalogue. Scombrids of the world. An annotated and illustrated catalogue of tunas, mackerels, bonitos and related species known to date. FAO Fish Synop 125:137

Fauvelot C, Borsa P (2012) Patterns of genetic isolation in a widely distributed pelagic fish, the narrow-barred Spanish mackerel (Scomberomorus commerson). Biol J Linn Soc 104:886-902

Felsenstein J (1985) Confidence limits on phylogenies: an approach using the bootstrap. Evolution 39:783-791

Grave JE, Ferris SD, Dizon AE (1984) Close genetic similarity of Atlantic and Pacific tuna (Katsuwonus pelamis) demonstrated with restriction endonuclease analysis of mitochondrial DNA. Mar Biol 79:315-319

Hoolihan JP, Anandh P, Herwerden LV (2006) Mitochondrial DNA analyses of narrow-barred Spanish mackerel (Scomberomorus commerson) sugest a single genetic stock in the ROPME sea area (Arabian Gulf, Gulf of Oman and Arabian Sea. ICES J Mar Sci 63:1066-1074

Irwin DM, Kocher TD, Wilson AC (1991) Evolution of the cytochrome $b$ gene of mammals. J Mol Evol 32:128-144

Johnson MG, Mgaya YD, Shaghude YW (2015) Mitochondrial DNA analysis reveals a single stocks of Frigate tuna Auxis thazard in the northern coastal waters of Tanzania. IOTC- WPNT05-16 Rev_1

Kailola PJ, Williams MJ, Stewart PC, Reichelt RE, McNee A, Grieve C (1993) Australian fisheries resources. Bureau of Resource Sciences Canberra, Canberra, p 422

Kikkawa Y, Takada T, Sutopo Nomura K, Namikawa T, Yonekawa H, Amano T (2003) Phylogenies using mtDNA and SRY provide evidence for male-mediated introgression in Asian domestic cattle. Genet 34:96-101

Kimura M (1980) A simple method for estimating evolutionary rate of base substitutions through comparative studies of nucleotide sequences. J Mol Evol 16:111-120

Kumar G, Kunal SW, Menezes MR (2012) Genetic stock structure of Frigate tuna (Auxis thazard) along Indian coast based on PCR-RFLP analysis of mtDNA D-loop region. Turk J Fish Aquat Sci 12:893-903

Kumar G, Kunal SW, Menezes MR, Kocour M (2014) Genetic divergence between Auxis thazard and A. rochei based on PCRRFLP analysis of mtDNA D-loop region. Turk J Fish Aquat Sci 14:539-546

Kunal SP, Kumar G, Menezes MR, Meena RM (2013) Mitochondrial DNA analysis reveals three stocks of yellowfin tuna Thunnus albacares (Bonnaterre, 1788) in Indian waters. Conserv Genet 14:205-213

Loftus RT, MacHugh DE, Bradley DG, Sharp PM, Cunningham P (1994) Evidence for two independent domestications of cattle. Proc Natl Acad Sci 91:2757-2761

Mannen H, Tsuji SR, Loftus T, Bradley DG (1998) Mitochondrial DNA variation and evolution of Japanese black cattle (Bostaurus). Genet 150:1169-1175

Menezes MR, Ikeda M, Taniguchi N (2006) Genetic variation in skipjack tuna Katsuwonus pelamis (L.) using PCR-RFLP analysis of mitochondrial DNA D-loop region. J Fish Biol 68:156-161

Menezes R, Noguchi D, Nakajima M, Taniguchi N (2008) Microsatellite development and survey of genetic variation in skipjack tuna Katsuwonus pelamis. J Fish Biol 73:463-473

Menezes MR, Kumar G, Kunal SP (2012) Population genetic structure of Skipjack tuna Katsuwonus pelamis from the Indian coast using sequence analysis of the mitochondrial DNA D-loop region. J Fish Biol 80:2198-2212

Mudumala VK, Somvanshi VS, Lakra WS (2011) Phylogenetic relationships of coastal tunas inferred from mitochondrial DNA sequences in the cytochrome c oxidase I (COI) gene-a study on DNA barcoding. IOTC-2011-WPNTO1-12

Pauly D, Cabanban A, Torres FBS Jr (1996) Fishery biology of 40 trawl-caught teleosts of western Indonesia, 135-216

Pesole G, Gissi C, de Chirico A, Saccone C (1999) Nucleotide substitution rate of mammalian mitochondrial genomes. J Mol Evol 48:427-434

Roldan-Ruizi, Dendauw J, Van Bockstaelee, Depicker A, De Loose M (2000) AFLP markers reveal high polymorphic rates in ryegrasses (Lolium spp.). Mol Breed 6:125-134

Saitou N, Nei M (1987) The neighbor-joining method: a new method for reconstructing phylogenetic trees. Mol Biol Evol 4:406-425

Smith BL, Bremer RA (2010) High-resolution melting analysis (HRMA): a highly sensitive inexpensive genotyping alternative for population studies. Mol Ecol DNA Resour 10:193-196 
Tamura K, Stecher G, Peterson D, Filipski A, Kumar S (2013) MEGA6: molecular evolutionary genetics analysis version 6.0. Mol Biol Evol 30:2725-2729

Tudela S, Garcia-Marin JL, Pla C (1999) Genetic structure of the European anchovy, Engraulis encrasicolus L., in the north-west Mediterranean. J Exp Mar Biol Ecol 234:95-109

Waples RS (1998) Separating the wheat from chaff: patterns of genetic differentiation in high gene flow species. J Hered $89: 438-450$

Ward RD, Woodmark M, Skibinski DOF (1994) A comparison of genetic diversity levels in marine, freshwater and anadromous fishes. J Fish Biol 44:213-232 